\title{
The role of promotion expenditures, direct flights and climate in island destinations
}

Journal of Vacation Marketing

$1-18$

(C) The Author(s) 2021

Article reuse guidelines:

sagepub.com/journals-permissions DOI: $10.1177 / 13567667211020492$

journals.sagepub.com/home/jvm

@SAGE

\author{
Susana Cró \\ CEFAGE-UE and Universidade de Évora, Portugal
}

Pedro Correia

Universidade da Madeira, Portugal

\section{António Miguel Martins (1)}

Universidade da Madeira, Portugal; Centre of Applied Economic Studies of the Atlantic (CEEApIA), Portugal

\begin{abstract}
The purpose of this study is to investigate the importance of promotion expenditures, direct flights, and climate, among other variables commonly used in gravity models, in the attractiveness of international tourists to an insular destination, in this particular case, Madeira. These three variables are rarely present in gravity models that analyse international demand. Given the possibility of endogeneity, a dynamic model is estimated for the annual panel data set of the 13 main tourist-generating markets for Madeira between 2005 and 2018. The results indicate that traditional gravity variables are significant in explaining international demand. They also show that promotion expenditures, climate, and the number of direct flights are important competitive factors. Promotion expenditures are of fundamental importance given the weight of the tourism sector in insular economic activity. Our results contribute to the debate that has already started about effective tourism policy making and strategies in the postpandemic of COVID-19.
\end{abstract}

Keywords

Dynamic model, gravity model, international tourism demand, islands, panel data

\section{Introduction}

For many islands, the tourism sector is one of the most important economic sectors, as is the case of Madeira, where tourism contributed with $25 \%$ of GDP and almost $20 \%$ of employment. Despite the importance of the tourism sector in insular destinations, these destinations tend to have various economic weaknesses and vulnerabilities, especially the handicap of distance and a crucial lack of competitiveness in most companies, due to the lack of economies of scale and the indivisibility of public goods and infrastructures (e.g., Dropsy et al., 2020).

The tourism sector, despite being undeniably an economic activity based on services, is also a tradable product with revenues from the foreign markets, with the act of consumption taking place with the displacement of the consumer to the destination. There is a pool of studies that has investigated the various determinants of international tourism demand empirically (for a comprehensive literature review, see for example Witt and Witt, 1995 and Song et al., 2019). The main determinants found to be important were the cost of travel, the income of the origin country, relative prices (relative cost of living and substitute price), among others. Among the

\footnotetext{
Corresponding author:

António Miguel Martins, Universidade da Madeira, Caminho da Penteada, 9020-105 Funchal, Portugal.

Email: antonio.martins@staff.uma.pt
} 
various models, the gravity model has been the model chosen by the researchers to analyse tourism flows.

To the best of our knowledge, this study is the first attempt to investigate the simultaneous role that promotion expenditures, direct flights, and climate have in the attractiveness of international tourists to an island destination, in this particular case, Madeira, using a well-accepted methodology in a dynamic context. Importantly, the dynamic panel data methodology adopted in this study accounts for the possibility of endogeneity in tourism. The emphasis given by us to these three variables is due to the substantial investment allocated by Madeira for tourism promotion expenditures, its airport being the main gateway for international tourists, and its climate being one of the main factors of competitiveness.

Most models have not attempted to assess the impact of promotional expenditures, direct flights, and climate upon international tourism demand. However, in the case of island destinations, most of these islands are only accessed by air, as is the case with Madeira. In this sense, international air connectivity between the departure and destination airport affects travel time, and, hence, the opportunity cost of travel. We cannot also ignore the importance of destination competitiveness components, although the extended gravity models that include them are scarce (Crouch, 2011). For example, GarínMuñoz and Montero-Martín (2007) and Chasapopoulos et al. (2014) mention the importance of the weather and climate in the choice of a holiday destination, in the specific cases in the choice of the Balearic Islands and Greece, respectively, but they do not include this variable in the estimation. In the case of Madeira, Oliveira and Pereira (2008) highlight the importance of climate as a competitive factor. They also emphasize the importance of this competitive factor for consumer loyalty to the destination, with tourists returning to Madeira and recommending this destination largely due to the climate. Finally, we study the impact of promotional expenditures in the insular context, given the importance of the tourism sector for most islands and the very substantial investment in tourism promotion made by the public authorities.

The results show a positive and statistically significant effect of the variables associated with the number of direct flights, climate, and promotional expenditures. This result reveals that in the insular context we must not ignore the influence of those three variables in attracting international tourists. The results of this study may be valuable for helping decision-makers, economic operators, and policy authorities in the decisionmaking process, related to enhancing the tourism industry in insular destinations. This analysis allows the identification of strategies that could be adopted to increase international tourism flows to insular destinations and thus increase overall destination competitiveness and profits.

The structure of the remaining paper is as follows. Section 2 provides a brief description of the tourism sector in Madeira. Section 3 presents the literature review. Data is presented in Section 4. The model specification and econometric model (GMM procedure) are covered and discussed in Section 5. Section 6 reports and discusses the results. Section 7 concludes the paper.

\section{Tourism in Madeira Island: Brief description}

The archipelago of Madeira which comprises two inhabited islands, Madeira and Porto Santo occupies an area of $801 \mathrm{Km}^{2}$. With a population of 254,254 (in 2019) ${ }^{1}$ and a density of 317,4 per $\mathrm{Km}^{2}$, the archipelago lies in the Atlantic North, in a region known as Macaronesia, $900 \mathrm{~km}$ from mainland Portugal and $450 \mathrm{~km}$ from the Canary Islands (Tenerife). Due to its volcanic origin, it is very mountainous, with a central mountainous area $1,800 \mathrm{~m}$ above sea level. The weather is always mild, with summer highs of $24^{\circ} \mathrm{C}$ and lows of $17^{\circ} \mathrm{C}$, while winter temperatures are $4^{\circ} \mathrm{C}$ lower. Sea temperature, due to the Gulf Stream, varies from $17^{\circ} \mathrm{C}$ to $22^{\circ} \mathrm{C}$.

Tourism has been the dominant sector of the economy and enjoys a centenary tradition as Madeira is one of the oldest touristic destinations in the world. In 2018, the tourism sector accounts for about $25 \%$ of GDP and almost $20 \%$ of employment. Owing to the archipelago's natural beauty and aesthetical landscapes, plus a mosaic of rich biodiversity, picturesque villages, and an overall ambience of security and calmness, the region has shown good dynamism in terms of attracting tourists, ${ }^{2}$ having received approximately $1,400,000$ tourists (a ratio of almost 6:1 to the local population) in 2018. Figure 1 shows the relative importance of each of the origin markets.

In terms of composition, it can be observed that international tourism is highly concentrated in three countries of origin. Germany, the UK, and France represent almost $71 \%$ of international arrivals in 2018. According to Oliveira and 


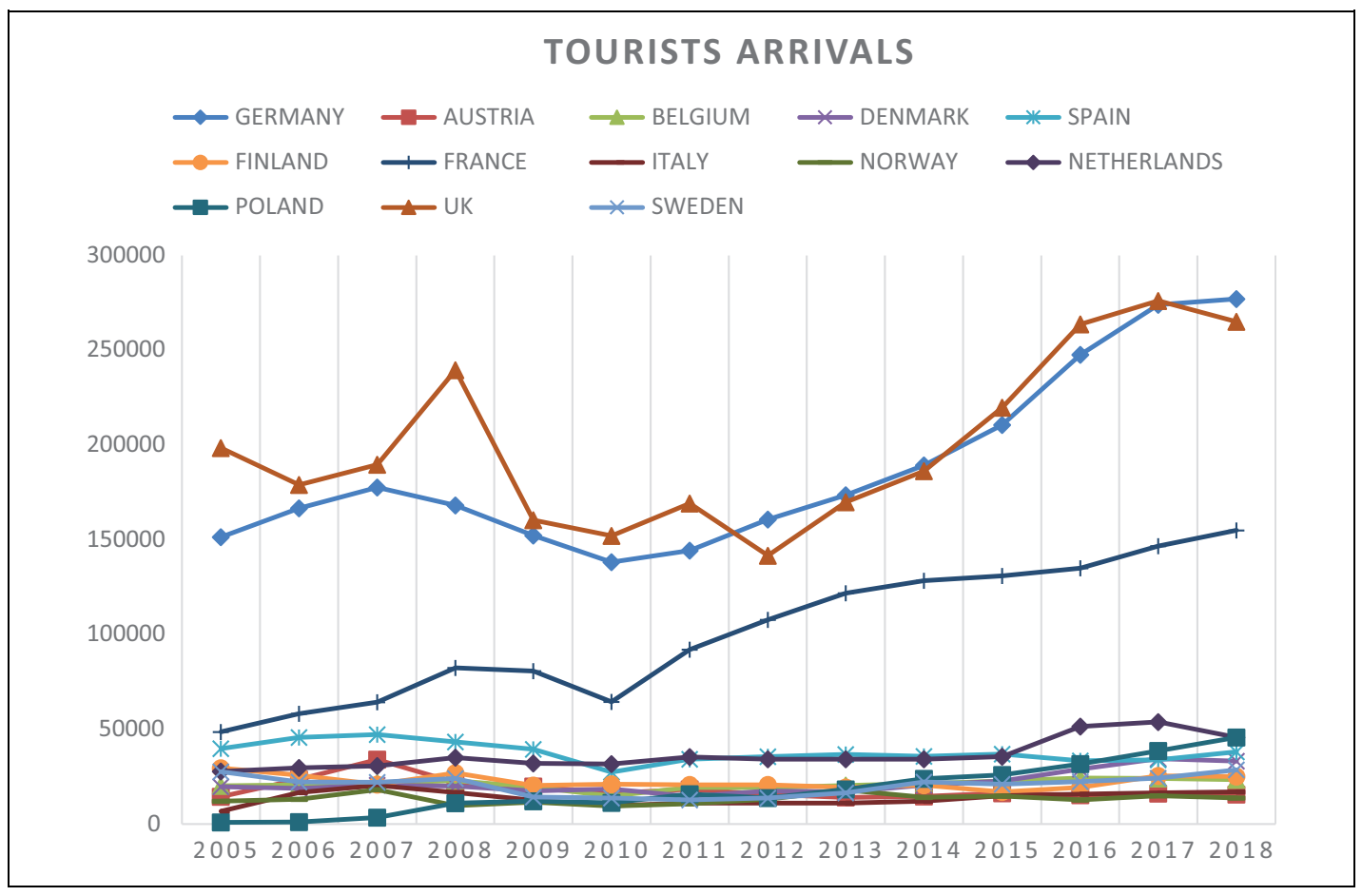

Figure I. Flow of tourists to Madeira between 2005-2018. Main source markets. Source: Tourism Series. Regional Directorate of Statistics of Madeira, which is available here: https://estatistica.madeira.gov.pt/en/.

Pereira (2008), the tourists make their decision to visit Madeira, essentially due to the following five aspects: landscape, weather, flora, levadas ${ }^{3}$ (man-made water channels with pathways used to check their condition) and walks. The authors refer that, in the case of the British tourists, the weather is the most valuable asset of Madeira. The mild climate and the influence it was believed to have on people's health has been, for more than a century, the main attraction of the destination (e.g. Oliveira and Pereira, 2008). Finally, the geographical location, sufficiently close to the European Mainland to allow 3-4 hours' flights from North Europe and close enough to Africa to offer an exotic flair and aesthetical pleasant landscapes should be fully considered as comparative advantages.

\section{Literature review}

\section{I. Gravity models in tourism}

The analysis of international tourism demand in the majority of published empirical studies is based on the gravity model of trade (e.g., Park and Jang, 2014; Petit and Seetaram, 2019; Tatoglu and Gul, 2020; Xu et al., 2019; Witt and Witt,
1995). The gravity models were built based on Newton's universal law of gravitation, which states (in the tourism context) that the degree of bilateral flows between two geographic areas is directly proportional to the countries' economic masses and inversely proportional with the distance separating them. The most common form of travel gravity model can be expressed as:

$$
Y_{i j t}=\beta_{0} \frac{X_{i t}^{\beta_{1}} X_{j t}^{\beta_{2}}}{D_{i j}^{\beta_{3}}} \mu_{i j t},
$$

where $Y_{i j t}$ denotes the international tourism flow between location $I$ and $J$ at time $t . \mathrm{X}_{\mathrm{it}}$ and $\mathrm{X}_{\mathrm{jt}}$ are the economic sizes of the two locations at time $t$. $X$ is generally the gross of domestic product (GDP). GDP is traditionally used in the gravitational models to represent the 'mass' effect. As explained by Petit and Seetaram (2019: 1267), 'the bigger the country is, the more important is the volume of trade between them'. $D_{i j}$ is the distance between the locations. This 'distance' can have physical, psychological, social, cultural, and economic components (e.g., Morley et al., 2014; Petit and Seetaram, 2019). Lorde et al. (2016) use in replacement of geographical distance, in their augmented gravity approach the geographic distance multiplied by the average oil 
price. The same procedure is adopted by us in the present study. $\mu_{i j t}$ is a log-normally distributed error term. $\beta$ are parameters to be estimated. For estimation purposes, equation (1) can be transformed using natural logarithms to:

$$
\begin{aligned}
& \operatorname{Ln} Y_{i j t}=\beta_{0}+\beta_{1} \operatorname{LnGDP} P_{i t}+\beta_{2} \operatorname{LnGDP} P_{j t} \\
& +\beta_{3} L n D_{i j}+\mu_{i j t}
\end{aligned}
$$

In this simple version of the gravitational model, the physical distance between two locations was viewed as a surrogate measure for all of the various costs associated with travel (e.g., Park and Jang, 2014).

However, as explained by Park and Jang (2014), recent empirical studies have attempted to refine gravity models by adding more explanatory variables to the base model presented in Equation 1. According to the authors, a modelbased only on so-called gravity variables (i.e., physical distance and economic size) leaves no scope for policymakers to change and improve the international tourism flows. Consequently, the most recent empirical studies largely adopted extended gravity models, where tourism flows arise as a function of a matrix of interrelated factors, to obtain a holistic explanation of tourist flows, that includes common demand factors (i.e., income, substitute prices, relative price, and transport costs), transportation infrastructures, as well as economic and non-economic factors (Park and Jang, 2014).

Table 1 summarizes the economic and noneconomic factors included in 21 empirical studies on international tourism flows, on which we rely to carry out this empirical study. We are especially interested in empirical studies that used the gravity model, which focused on island destinations and that analyse the role of the variables highlighted in this study - promotion expenditures, direct flights, and/or climate.

From the analysis of Table 1, we can conclude that no previous study has analysed the simultaneous impact of destination promotion expenditures, direct flights, and climate on island destinations. Thus, there is a gap in the literature that this article aims to fill. To our best knowledge, this study is the first attempt to investigate the simultaneous role that promotion expenditures, direct flights, and climate have in the attractiveness of international tourists to an island destination. The following section presents studies that used these variables as well as their main conclusions.

\subsection{Promotion expenditures, direct flights and climate in the tourism literature}

This section summarizes the studies that used the variables promotion and climate in their empirical analyses as well as their main conclusions. Promotion expenditures are expected to play a key role in international tourism demand. Nevertheless, promotion expenditures have not featured often in tourism demand models (e.g., Crouch et al., 1992; Witt and Witt, 1995). As is emphasized by Crouch et al. (1992: 199), 'although many of these studies have recognized the potential impact of marketing expenditures on demand only a few studies have attempted to model the effect'. One of these exceptions is the study of Ledesma-Rodríguez et al. (2001) for the island of Tenerife. They show that promotional expenditures seem to have only a small influence on the number of tourists. Two other studies have measured the return of tourism marketing expenditure in Australia and Hong Kong, using a dynamic modelling approach and costeffectiveness analysis (Kulendran and Dwyer, 2009; Zhang et al., 2010). Their results have practical implications by targeting the highest yield markets to increase the economic returns to Australia and Hong Kong, respectively, from their destination marketing activity.

Two other previous studies show mixed results on the impact of promotion expenditures on the arrival of tourists. While Crouch et al. (1992) show empirically that the international marketing activities of the Australian Tourist Commission have played a statistically significant role in influencing inbound tourism, Uysal and Crompton (1984) show that investments in promotion in Turkey as a tourist destination are likely to have minimal impact on international tourist flows to Turkey. The evidence presented in these last two studies should be read with caution since both studies use static models of linear regression.

Another important determinant in attracting international tourists to island destinations is the availability of direct flights. Park and Pan (2018) refer to the importance of identifying and eliminating barriers to travel in order to increase the flow of tourists. According to Grosche et al. (2007), the lack of a non-stop route can be a barrier for tourists from potential markets to reach a destination. Nicolau and Màs (2006) and Tveteras and Roll (2014) highlight that non-stop flights can mitigate some of the negative effects of distance on tourism arrivals such as the 


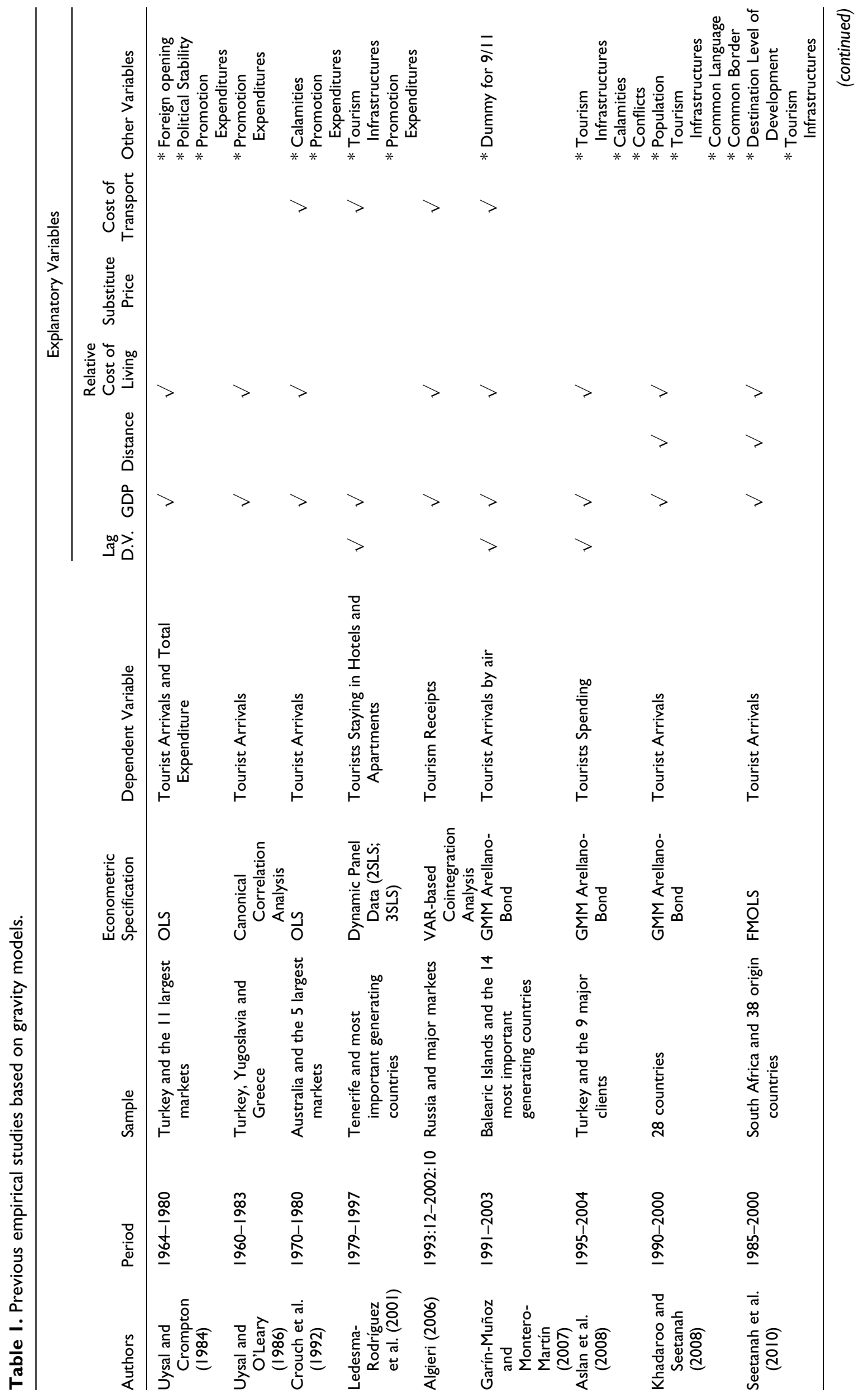




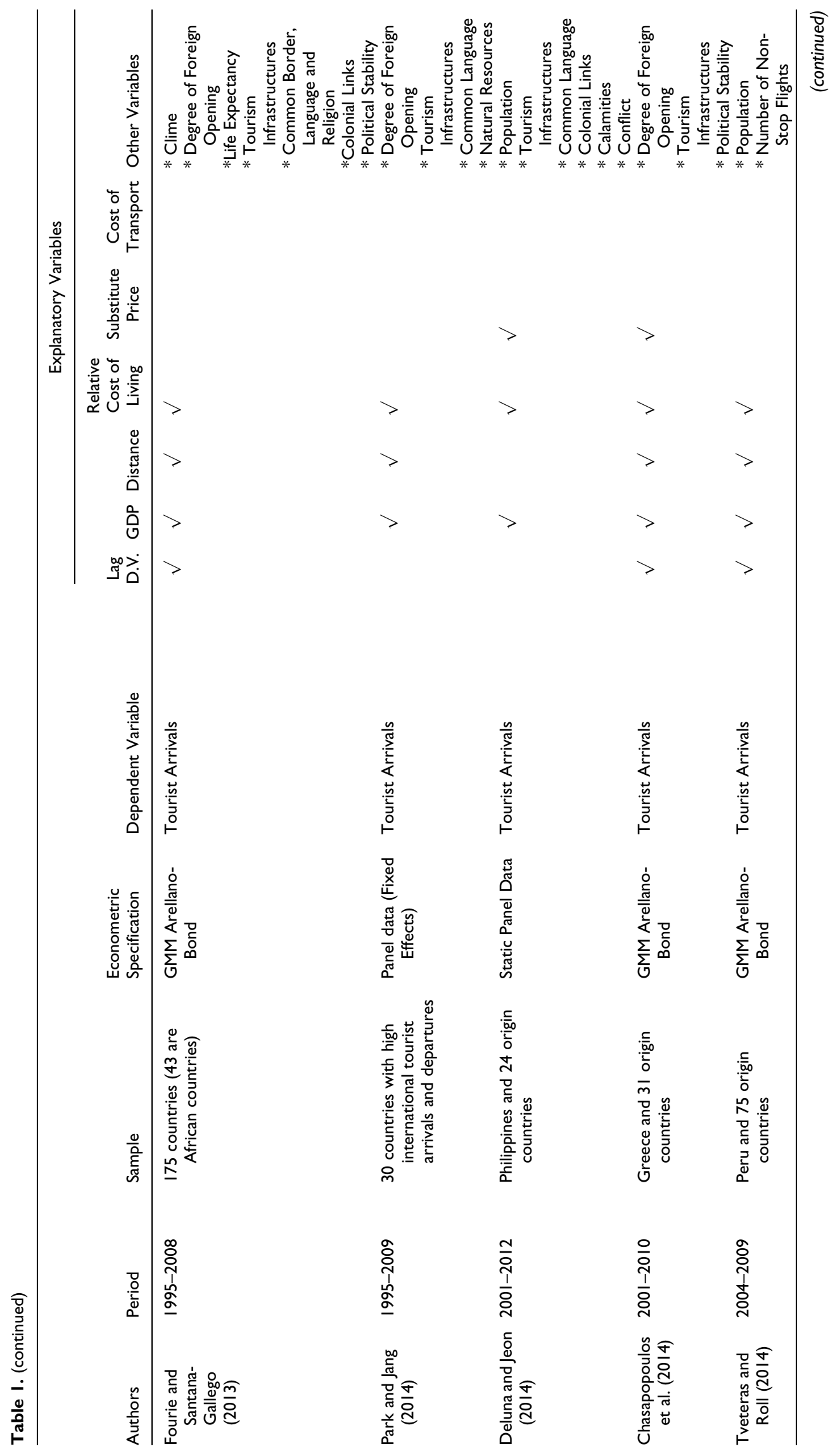




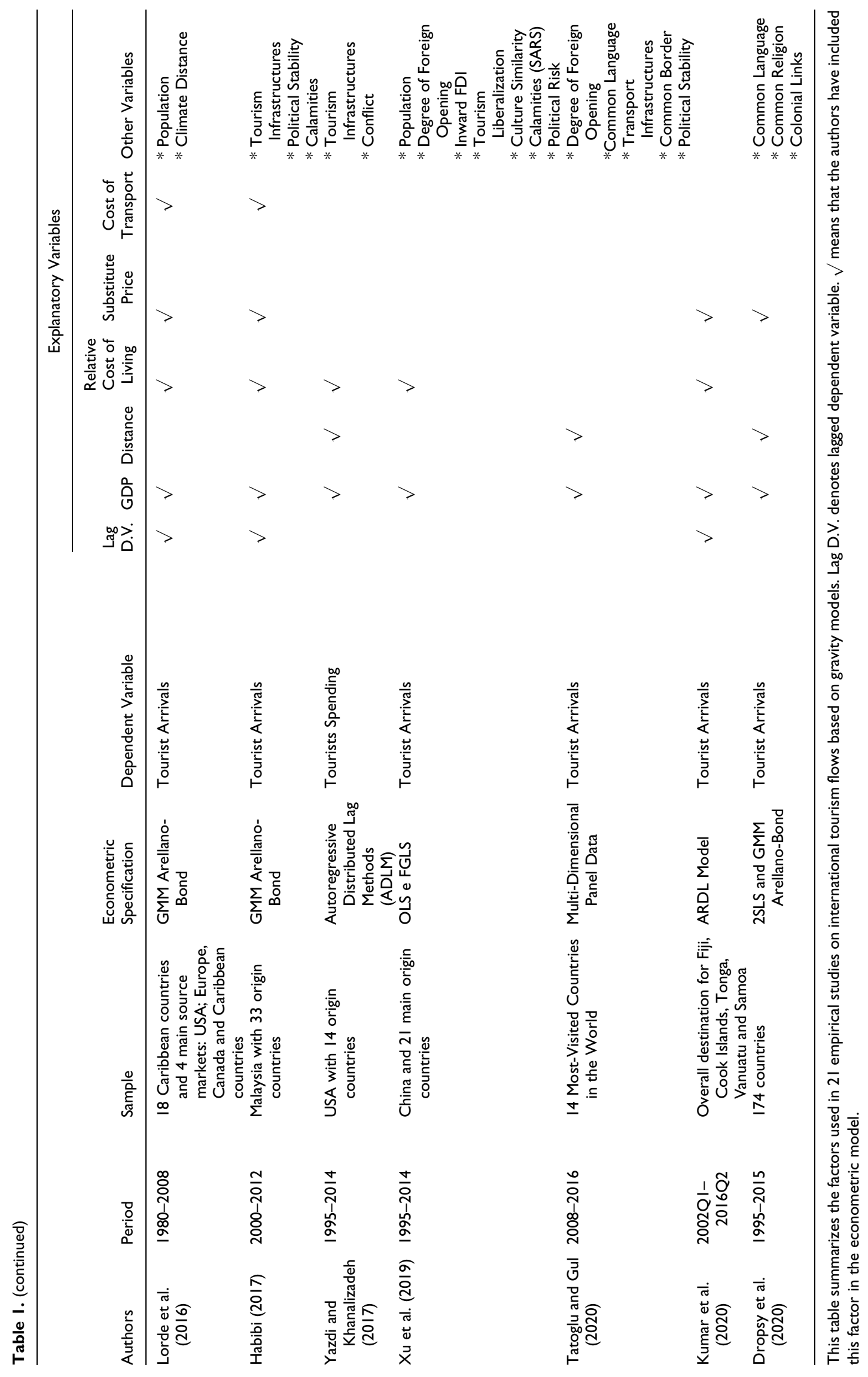


opportunity cost of travel, time, and convenience associated with travel.

Therefore, the availability of a direct flight would come into the decision-making process and given that direct flights can potentially reduce transportation cost, should be included in the gravity model as a cost factor (Park and Pan, 2018). Creating a direct flight can function as a mechanism to increase the number of passengers for airlines and the number of tourists to the destination (e.g., Deluna and Jeon, 2014; Fujii et al., 1992; Nicolau and Màs, 2006; Park and Jang, 2014; Tveteras and Roll, 2014).

Despite the importance of the existence of direct flights to increase the arrivals flow, especially in the island context, Tveteras and Roll (2014) note that this specific issue of non-stop flight connectivity has received little attention. The exceptions are the studies of Fujii et al. (1992) and Deluna and Jeon (2014), which investigate the impact of direct flights on Hawaii and the Philippines, respectively. Both studies have islands as a destination and both studies conclude that direct flights from origin to destination will increase tourism arrivals.

In the particular case of air transportation infrastructures, Park and Jang (2014) state that in the case of destinations that cannot be reached by ground (Australia in the case described), authorities must consider air transportation infrastructures as a priority issue to attract more tourists. The issue of direct flights cannot be ignored by this strategy.

Finally, for a large part of island destinations, the climate tends to be a factor of competitiveness. Among the various categories of destination competitiveness components described in Crouch (2011), Oliveira and Pereira (2008) highlight the importance of landscape and climate components for Madeira Island. Oliveira and Pereira (2008) use an order probit model to study the importance placed on different aspects of Madeira when tourists make their decision to visit that destination and they conclude that landscape, weather, flora, levadas and walks are the five aspects with the highest percentage of answers of the high, very high or highest importance. In the case of British tourists, the weather is the most valuable asset of Madeira. All these five factors are related to nature and climate. The regional strategy for Madeira tourism ${ }^{4}$ also enshrines these two vectors as key drivers of destination competitiveness.

Despite the importance of destination competitiveness components, the extended gravity models that include them are scarce. For example, Garín-Muñoz and Montero-Martín (2007) and Chasapopoulos et al. (2014) mention the importance of the weather and climate in the choice of a holiday destination, in the Balearic Islands and Greece, respectively, but they do not include this variable in the estimation. However, there are some exceptions, such as Fourie and Santana-Gallego (2013) and Lorde et al. (2016), who analyse the impact of the climate in attracting tourists in Africa and Caribbean destinations, respectively. Both studies show a positive and significant effect of climate on international tourism demand. The two studies differ, however, in the way they measure the climate. Fourie and Santana-Gallego (2013) use the average annual temperature of each destination country (in degree Celsius). Lorde et al. (2016) consider the difference in climate between origin and destination and employ a tourism climatic index (weighted average of seven climatic variables, which includes temperature, humidity, precipitation, wind speed, and hours of sunshine values).

\subsection{The problem of insularity in the tourism sector}

There is some consensus in the literature regarding the economic vulnerabilities of small islands. According to Winters and Martins (2004), these islands will not be suitable locations for industry or even tourism unless they have very specific advantages that allow them to charge substantially higher prices than the median island/ country.

Therefore, these islands tend to suffer dramatic cost disadvantages, due to the lack of economies of scale and the indivisibility of public goods and infrastructures. Dropsy et al. (2020) show that small islands (territories with a population inferior to one million inhabitants) tend to be relatively more at disadvantage for tourism than other destinations, for two reasons: $i$ ) lack of an adequate labour supply; ii) very small and less populated islands cannot afford the kind of infrastructures needed to develop international tourism due to the lack of significant economies of scale in the cost of building ports, airports, as well telecommunications and health care infrastructures. The theme of transports, namely the frequency of flights and the lack of direct connections affect the attractiveness of the destination. For example, Fujii et al. (1992: 185) refer that 'resort destinations that can be reached only through a hub become less 
attractive, given that imposes additional uncertainty, time, and inconvenience costs on travellers.

Dropsy et al. (2020: 792) also highlight the 'three-dimensional challenge' that small island countries must overcome: distance, density, and division. According to the authors, islands tend to be badly ranked in these three dimensions, given that, on average, they tend to be away from large markets, they have very low economic density, and they suffer from acute geographical divisions from being sea-locked and isolated, as well as artificial divisions from their very often protectionist trade policies, which generate large inefficiencies and low competitiveness.

Despite the huge competitive challenges, the small islands have their specific advantages (case of climate and exceptional scenery) that could be an advantage when aiming at the high-end niche tourism market and charge a high price premium. Therefore, for hotels and tourism, the attractions of small islands are plausible, and we see viable tourist industries on them, but they will need to manage costs carefully and will never achieve mass-market penetration (Dropsy et al., 2020; Winters and Martins, 2004).

\subsection{Role of promotion tourism organizations}

Faulkner (1997) identifies the following functions that NTAs may undertake: marketing, visitor servicing, development, planning, research, coordinating, and lobbying. In its turn, Pike and Page (2014) highlight the importance of the Destination Marketing Organisation (DMO) as the main vehicle to compete and attract visitors to their distinctive place or visitor space.

Having reached this point, it is important to take into account the six reasons for government intervention in tourism (e.g., Jeffries, 2001: 105-113): $i$ ) wider objectives; $i i$ ) the importance of transport policy; iii) the complexity of tourism; $i v$ ) market failure; $v$ ) public sector provision of leisure service; and $v i$ ) resolution of conflict. If it is true that the free market is the most efficient means of allocating resources available, it is also true that when the market is imperfect, the government intervention is justified.

Market failure occurs where there are public goods, ${ }^{5}$ externalities, and market power. Private provision of destination promotion suffers from being a public good; if some businesses were to collectively advertise their destination, other businesses would be able to free-ride on this promotion, and the original businesses would have no incentive to stay within such a voluntary scheme (e.g., Lundtorp, 2003). Destination promotion therefore needs some form of public involvement, through direct government provision or compulsory membership schemes. This public good characteristic of destination promotion applies on a large scale to regional/national promotion. It is in the interest of most tourism businesses to try attracting international visitors, yet each individually has little incentive to spend money on regional/national promotion activities (e.g., Atkinson and Stiglitz, 2015; Lundtorp, 2003)

Fayos-Solá (1996) states that it is difficult to find sectors of activity where external effects play such an important role as in tourism, or where the provision of specific categories of information or urban infrastructures or communications have a more crucial nature. Destination promotion, therefore, needs some form of public involvement, through direct government provision or compulsory membership schemes. This public good aspect of destination promotion applies on a larger scale to national promotion.

Despite the public good nature of destination promotion activities, there has been some criticism in the literature of the role played by NTAs. Hay (2019b) argues that NTAs seem to be more concerned about their own survival, rather than providing a service to both their residents and tourists. He also argues that with increasing urbanization, tourists are much more likely to be receptive to focused city/region marketing campaigns rather than vague national/country marketing campaigns (Hay, 2019a). Cities with their high tax base, efficient transport links, large population, quality starchitect-built attractions, will increasingly become much more self-governing, and less dependent on NTA's to attract tourists.

\subsection{Determinants of international tourism flows}

3.5.I. Dependent variable: International tourist arrivals. As reviewed by Song et al. (2019), tourism demand has been defined by a host of variables. Frequently, tourist arrivals, overnight stays, or receipts from tourism have been the most used variables for the analyses in the literature (e.g., Khadaroo and Seetanah, 2008).

Ideally, one would want to measure foreign tourism demand by a combination of the three variables mentioned above (e.g., Chasapopoulos et al., 2014). However, this appears unfeasible 
due to the great complexity involved in constructing data for such data. Furthermore, data on tourism expenditure are rarely available (e.g., Chasapopoulos et al., 2014). Song et al. (2019), who carried out a review of $211 \mathrm{key}$ papers of tourism demand forecasting between 1968 and 2018, conclude that the total number of tourist arrivals remains the most used method for measuring tourism demand. Table 1 also shows this pattern. The present study follows this strand of literature.

3.5.2. Independent variables. The independent variables used to estimate the extended gravity model are presented below.

Lagged dependent variable: Habit persistence (word-of-mouth). Several studies on the international flow of tourists have included a lagged dependent variable in their models (see Table 1). As explained by Witt and Witt (1995), Ledesma-Rodríguez et al. (2001), Fourie and Santana-Gallego (2013), Garín-Muñoz and Montero-Martín (2007), Lorde et al. (2016) and Habibi (2017) the dependent variable can be justified on the grounds of habit persistence (word-of-mouth). They argue that are 'persistence/reputation effects' that apply overtime in the destination decision, for instance by tourists returning to a particular destination or recommending a country to friends and relatives, after having a good experience. There is much less uncertainty associated with holidaying again in that country compared with travelling to a previously unvisited foreign country.

Ledesma-Rodríguez et al. (2001), Fourie and Santana-Gallego (2013), Garín-Muñoz and Montero-Martín (2007), Lorde et al. (2016) and Habibi (2017) show that lagged tourist arrival variable is significantly positive, suggesting that repeat tourism is of utmost importance for inbound tourism.

Economic size: GDP per capita. In empirical studies of international demand, the GDP per capita (in the origin countries) must be the first considered (e.g., Witt and Witt, 1995; Habibi, 2017; Xu et al., 2018). The range of income measures reported in the survey by Witt and Witt (1995) is [0.4 to 6.6]. According to the authors, in most of the studies, the estimated income elasticities exceed unity, showing that foreign tourism is generally regarded as a luxury. In fact, economic theory considers foreign holidays to be 'superior' goods, and thus an increase in income is expected to increase demand. More recently, it is possible to find empirical studies that demonstrate that tourism is a luxury good, given that its share in consumption spending increases more than proportionally when real incomes rise. It is the case of Ledesma-Rodríguez et al. (2001) for Tenerife, Algieri (2006) for Russia or Kumar et al. (2020) for Pacific Islands countries.

Geographical distance proxy. Like Lorde et al. (2016), we use a measure of transportation costs between Madeira and source markets in replacement of geographical distance. Transport costs are a complementary tourism price indicator because these costs often represent a relatively large share of the total tourism expenditure (e.g., Kumar et al., 2020; Witt and Witt, 1995). Transportation costs in gravity models are generally proxied by the distance between origin and destination countries due to complexities of the price structure of transportation and the lack of consistent data (e.g., Witt and Witt, 1995). Like Lorde et al. (2016) and Habibi (2017), we multiply the geographic distance (using the great circle formula) with the average oil price to estimate transportation costs.

The disadvantage of using geographic distance as a proxy for transportation cost is that is time-invariant. Seetaram (2010) highlights that airfares might be a better measurement for transportations costs; however, the wide unavailability of airfare data restricts us from consider the best alternative. According to Seetaram (2010: 32) 'the two most commonly used proxies are the price of crude oil and the physical distance between the home country and destination'. However, as is demonstrated by Seetaram (2010), these variables may be far from being ideal proxies, that is, from being variables that are highly correlated with airfare and uncorrelated with any of the other independent variables in the model. But possible biases tend to be extenuated to some extent using panel data estimation techniques (Seetaram, 2010). This variable is expected to have a negative effect on inbound flows.

Relative cost of living. Table 1 reveals that the relative cost of living is a consensual variable in the gravity models, in the study of international tourist flows. An increase in the price level of the destination to the origin country discourages tourists to travel to this place or reallocates their demand to other relatively cheaper alternative tourism destinations. In our study, we adopt a measure of relative prices commonly accepted 
in conventional models of tourist demand. The relative cost of living is formalized as:

$$
R C L_{m j t}=\frac{C P I_{m t}}{C P I_{j t} * E_{€ / j}}
$$

where $E_{€ / j}$ is the nominal effective exchange rate between euro (currency in Madeira) and source market $j$ currency, $C P I_{m}$ and $C P I_{j}$ are the price indices of Madeira and source market $j$, respectively. Tourists are usually more aware of exchange rates than of relative prices because they are better informed about the former. The exchange rate has long been used as the proxy for prices in tourism demand models (e.g., Seetaram et al., 2016). However, although the exchange rate at a given destination may become more favourable to tourists, its apparent cheapness could still be offset by a high inflation rate (e.g., Algieri, 2006). The variable has some limitations, ${ }^{6}$ particularly when it comes to models of outbound tourism (e.g., Seetaram et al., 2016). An alternative measure - a price competitiveness index, is proposed by the authors to be used as a proxy for prices in a model of outbound tourism. According to theoretical hypotheses, the relative cost of living variable is associated negatively with Madeira inbound tourist arrivals (e.g., Deluna and Jeon, 2014; Xu et al., 2018).

Substitute price. In addition to the relative cost of living variable is common to employ another price variable - the substitute price (e.g., Chasapopoulos et al., 2014; Habibi, 2017; Kumar et al., 2020; Lorde et al., 2016). The effect of tourist price substitute is obtained through the ratio of the real cost of tourists in Madeira to a weighted average of the real costs of tourists in the selected complementary destinations. This study selected six direct competing destinations of Madeira (the Azores, Canary Islands, Balearic Islands, Malta, Greece, and Croatia) that were taken from a document in Portuguese entitled 'Estratégia para o Turismo da Madeira: 2017-2021' - translated means 'Strategy for Madeira Tourism: 20172021 ', 7 published by the regional government of Madeira. These six competing destinations obtained a large market share from the 13 main tourist-generating markets for Madeira. The substitute price index was calculated by weighing the average consumer price index of each of the six competing destinations according to its share of the international tourist arrivals as follows:

$$
S P_{j t}=\sum_{j=1}^{n} \frac{C P I_{j t}}{E R_{j t}} * W_{j t}
$$

where $C P I_{j}$ and $E R_{j}$ are, the consumer price index and the exchange rate of the competing destination currency country/region $j$, respectively. $W_{j}$ is the share of international tourist arrivals for country/region $j$, which is calculated as follows:

$$
W_{j t}=\frac{T A_{j t}}{\sum_{j=1}^{6} T A_{j t}}
$$

where, $T A_{j}$ means the tourist arrivals from country/region $j, \sum_{j=1}^{6} T A_{j t}$ total arrivals from country/region $j$.

Like the previous variable, the substitute price variable should be inversely related to demand. This means that higher prices in the destination relative to those in the origin market, as well as to prices in substitute destinations, should reduce flows to the destination market (e.g., Lorde et al., 2016).

Direct flights. Availability of a direct flight can function as one of the positive factors to keep the destination in one's choice set, given that a direct flight can decrease travel time, uncertainty, and discomfort (e.g., Nicolau and Màs, 2006; Tveteras and Roll, 2014). Having no direct flights can make the travel less comfortable and timeconsuming, and thus deter visitors. Our study includes a variable - Non-stop Flights - that counts the number of non-stop flights (direct flight routes) that depart annually from all airports located in the tourist's origin country $j$ to Madeira. An identical variable was used by Tveteras and Roll (2014).

Promotion expenditures. As highlighted in sections 3.2 and 3.4, the promotion expenditures are expected to play a key role in international tourism demand. The promotion expenditures by origin country to Madeira are used in the estimation of marketing expenditure elasticity as in Ledesma-Rodríguez et al. (2001), Kulendran and Dwyer (2009), and Zhang et al. (2010).

Destination competitiveness components: Climate and nature. Park and Jang (2014) refer that their extended gravity model had greater explanatory power than traditional gravity models, given that they include with gravity variables, destination competitiveness components (such as natural and cultural resources), tourism infrastructure, and price competitiveness. Regarding destination competitiveness components, Crouch (2011) has concluded that core resources and attractors were the most important and determinant factors in 
destination competitiveness. Among the various categories of destination competitiveness components mentioned in Crouch (2011), Oliveira and Pereira (2008) highlight the importance of landscape and climate components for Madeira Island.

We agree with Lorde et al.'s (2016) argument that climate conditions in both origin and destination should be considered in modelling of tourism demand and the difference between each other may influence tourism demand, but we use the difference in terms of average annual temperature between the destination and origin as climate proxy (as in Fourie and SantanaGallego, 2013) since it is the only information available in terms of climate for Madeira and source markets.

Calamities and financial crisis dummies. Finally, we also include in the extended gravity model the effect of calamities and financial crisis in international tourist demand for Madeira. We include a dummy that aims to capture the impact of natural disasters (floods and mudslides) that occurred in $2010^{8}$ in Madeira and the effect of the financial crisis of 2008-2010. According to Cró and Martins (2017), these events have caused a structural break in Madeira tourism demand, so dummies should be included for that period so that there is no bias in the estimates.

\section{Data}

We analyse the demand for Madeira Island international tourism by using data on the number of tourists arriving from the 13 major origin countries. These 13 origin countries are Germany, the United Kingdom, France, Austria, Belgium, Denmark, Spain, Finland, Italy, Norway, Netherlands, Poland, and Sweden. The data set corresponds to the annual tourists' arrivals during the period between 2005 and 2018. Therefore, we have a complete data set with 169 observations. The dependent variable of international tourist flow was collected from the Regional Directorate of Statistics of Madeira, whose website is https:// estatistica.madeira.gov.pt/en/ and by the company that manages Madeira airport (ANA Madeira Aeroportos), through the series 'Evolution of Passengers by Market - Country of Origin'.

The GDP per capita in PPP (in the origin countries) data was obtained from the website for the World Development Indicators (WDI) of the World Bank. ${ }^{9}$ The geographical distance between the origin and destination countries and average oil price, used in the construction of the variable transportation costs, was taken from CEPII (Centre d'Études Prospectives et d'Informations Internationales) statistics ${ }^{10}$ and World Bank Commodity Price Data, respectively. In the construction of the variables relative cost of living and substitute price, the nominal effective exchange rates were collected from the International Financial Statistics database of the International Monetary Fund. ${ }^{11}$

The consumer price indices of Madeira, origin, and competing destinations were collected from the Regional Directorate of Statistics of Madeira and WDI of World Bank, respectively. The number of non-stop flights that depart annually from tourist's origin countries to Madeira was collected from ANA - Madeira Aeroportos. The promotion expenditures by origin country were extracted from Madeira Promotion Bureau. ${ }^{12}$ Finally, the difference in climate between origin and destination (average temperature) was built with information obtained about the average temperature in Madeira and origin country, that was collected from Funchal Meteorological Observatory ${ }^{13}$ and National Centers for Environmental Information (NOAA) ${ }^{14}$ respectively.

\section{Model specification and econometric method}

The proposed extended gravity model is estimated in a panel data framework. According to Hsiao (2014) the methodology of panel data has advantages over conventional time-series or crosssection data, such as $i$ ) more accurate inference of model parameters; $i i$ ) greater capacity for constructing more realistic behavioural hypothesis; iii) allows good estimations of dynamics relationships; iv) enables us to control the impact of omitted variables; $v$ ) generates more accurate predictions for individual outcomes and $v i$ ) provides micro-foundations for aggregate data analysis.

However, the possibility of endogeneity and the dynamic nature of international tourist flows, makes it impossible to use a static panel data framework. The inclusion of the lagged dependent variable allows us to measure the habit formation and preferences of visitors, but it brings a dynamic structure into these preferences that can only be studied with a dynamic structure (e.g., Garín-Muñoz and Montero-Martín, 2007; Habibi, 2017; Khadaroo and Seetanah, 2008). Given that the number of time periods is not 
Table 2. Estimation results for the dynamic models (GMM-DIFF estimator of Arellano and Bond).

\begin{tabular}{|c|c|c|c|c|c|c|}
\hline \multirow[b]{2}{*}{ Variables } & \multicolumn{2}{|c|}{ Total Sample } & \multicolumn{2}{|c|}{ Major Markets } & \multicolumn{2}{|c|}{ Remaining Markets } \\
\hline & Coefficient & Z-statistic & Coefficient & Z-statistic & Coefficient & Z-statistic \\
\hline$\Delta \ln \mathrm{TA}_{(\mathrm{t}-1)}$ & 0.585 & $10.982 * * *$ & 0.463 & $2.918 * * *$ & 0.543 & $4.398 * * *$ \\
\hline$\Delta \operatorname{lnGDP}$ & 1.222 & I.804* & 1.252 & $1.902 *$ & 1.139 & I.865* \\
\hline$\Delta \operatorname{lnCT}$ & -0.157 & $-2.540 * *$ & -0.172 & $-2.404 * *$ & -0.120 & $-2.176 * *$ \\
\hline$\Delta \operatorname{lnRCL}$ & -0.858 & $-2.146 * *$ & -0.631 & $-2.222 * *$ & -0.966 & $-2.537 * *$ \\
\hline$\Delta \operatorname{lnSP}$ & -0.540 & $-1.918^{*}$ & -0.695 & $-2.182^{* *}$ & -0.490 & $-1.798 *$ \\
\hline$\Delta \operatorname{lnDF}$ & 0.227 & $4.946 * * *$ & 0.182 & $4.207 * * *$ & 0.300 & 3.140*** \\
\hline$\Delta \ln P E$ & 0.111 & $2.500 * *$ & 0.122 & $2.365^{* *}$ & 0.110 & $2.218^{* *}$ \\
\hline$\Delta \operatorname{lnDT}$ & 0.175 & $2.490 * *$ & 0.187 & $2.317 * *$ & 0.155 & $2.347^{* *}$ \\
\hline$D_{2008}$ to 2010 & -0.179 & $-4.319 * * *$ & -0.250 & $-2.257^{* *}$ & -0.066 & $-2.160 * *$ \\
\hline Diagnosis tests & Statistic & $p$ Value & Statistic & $p$ Value & Statistic & $p$ Value \\
\hline Wald Test & 176.36 & 0.002 & 129.44 & 0.000 & 145.66 & 0.007 \\
\hline Sargan test & 9.455 & 0.064 & 18.795 & 0.052 & 7.159 & 0.088 \\
\hline AR (I) test & -2.731 & 0.006 & -2.086 & 0.037 & -2.484 & 0.013 \\
\hline AR (2) test & 0.325 & 0.746 & -1.659 & 0.107 & 1.000 & 0.317 \\
\hline Number of Observations & \multicolumn{2}{|c|}{182} & \multicolumn{2}{|c|}{42} & \multicolumn{2}{|c|}{140} \\
\hline
\end{tabular}

This table presents the estimation results for the international tourism arrivals to Madeira, for the period between 2005 and 2018. Major Markets subsample includes the three most important origin markets for Madeira (Germany, the UK and France). Remaining Markets is a subsample of 10 countries obtained by eliminating from the analysis Germany, the UK and France. $\Delta$ denotes variables in first difference. The Wald Test indicates the joint significance of the explanatory variables. The Sargan chi-square statistic tests the null hypothesis of no correlation between the instrumental and residuals. The Arellano and Bond $Z$-statistics tests the null hypothesis that the residuals are first-order correlated $(A R(I))$ and the residuals are not second-order correlated $(\operatorname{AR}(2)) * * * * * *$ and $*$ denote statistical significance at $1 \%, 5 \%$ and $10 \%$, respectively.

large, and the lagged dependent variable is included as a regressor, both the ordinary least square and generalized least square are biased and inconsistent (e.g., Hsiao, 2014). An available solution to this problem is the estimation of the model using the GMMs procedure proposed by Arellano and Bond (1991). The model estimates are made in first differences and the values of the dependent variable lagged for two or more periods are used as instruments. As explained by Garín-Muñoz and Montero-Martín (2007) this procedure has two other advantages: $i$ ) it allows to obtain short-run and long-run elasticities and ii) avoid the problem of non-stationarity. Consistent and efficient estimators are obtained through this procedure (e.g., Hsiao, 2014).

Consequently, the dynamic model to be estimated can be described as follows:

$$
\begin{aligned}
\Delta \ln T A_{i, t}= & \beta_{1} \Delta \ln T A_{i, t-1}+\beta_{2} \Delta \ln G D P_{i, t} \\
& +\beta_{3} \Delta \ln C T_{i, t}+\beta_{4} \Delta \ln R C L_{i, t} \\
& +\beta_{5} \Delta \ln S P_{i, t}+\beta_{6} \Delta \ln D F_{i, t} \\
& +\beta_{7} \Delta \ln P E_{i, t}+\beta_{8} \Delta \ln D T_{i, t} \\
& +\beta_{9} \Delta d_{2008 \text { to } 2010}+\Delta \varepsilon_{i, t}
\end{aligned}
$$

where $T A_{i, t}$ denotes the number of international tourists arriving in Madeira from country $i$ during year $t$; $G D P_{i, t}$ is the GDP per capita in each of the origin countries; $C T_{i, t}$ means the cost of transport between each origin country and Madeira; $R C L_{i, t}$ denotes the relative cost of living; $S P_{i, t}$ means the substitute price; $D F_{i, t}$ is the number of direct flights that depart annually from the tourist's origin countries to Madeira; $P E_{i, t}$ denotes the promotion expenditures in each origin country; $D T_{i, t}$ is the difference in temperature between the capital of Portugal's Autonomous Region of Madeira (Funchal) and each origin country capital; $d_{2008}$ to 2010 is a dummy variable that captures the effect of the financial crisis and the natural disaster in 2010. All variables are in first differences $(\Delta)$. Given the double-logarithmic form of the dynamic model, the estimated parameters should be interpreted as short-run elasticities. Long-run elasticities can be obtained by dividing each of the coefficients by $\left(1-\beta_{1}\right){ }^{15}$

\section{Empirical results}

The empirical results for the dynamic panel regression model are reported in Table 2 . The consistency of the GMM estimator requires autocorrelation of the first order and the lack of second-order autocorrelation. The autocorrelation tests (Arellano and Bond, 1991) reveal that the subsequent lags are valid instruments. In addition, the Sargan test does not reject the null 
hypothesis for joint validity of the instruments. Diagnostic tests for the three samples show the consistency of the GMM estimator.

The lagged dependent variable reveals the presence of important habit persistence among international tourists, which could be interpreted as high consumer loyalty to the destination (high level of repeat visitation) and/or as an important word-of-mouth effect in the consumer's decision in favour of the destination. Similar results have been obtained in Balearic Islands (Garín-Muñoz and Montero-Martín, 2007), Africa (Fourie and Santana-Gallego, 2013), Caribbean Islands (Lorde et al., 2016), and Malaysia (Habibi, 2017).

The values of income elasticity -1.222 in the short-run and 2.944 in the long-run, since it exceeds unity, show that foreign tourism is regarded as a 'luxury good'. This variable shows that Madeira receives tourists who have relatively higher economic capacity. Consequently, the economic operators must maintain and, if possible, increase the high-quality standards of the products/services offered in order to keep attracting tourists with high purchasing power. The coefficients for the cost of transportation are negative and statistically significant. International tourist arrivals fall by approximately $1.6 \%$ and $3.8 \%$ in the near term and long term respectively for every $10 \%$ increase in the cost of transportation. Thus, despite the importance of habit persistence, demand tends to fall when the cost of travelling to Madeira increases. Tourism in Madeira is also very sensitive to prices (substitute price and relative cost of living). Both variables present negative and statistically significant elasticities. In the case of relative cost of living variable, for each $1 \%$ increase in destination prices, international arrivals fall $0.85 \%$ in the short-term. In the case of substitute price, short-term arrivals to Madeira decline by $0.54 \%$ for each $1 \%$ increase in the relative price of the destination to its competitors. The relatively high level of substitutability reflects the similarity of tourism in Madeira against its competitors (the Azores, Canary Islands, Balearic Islands, Malta, Greece, and Croatia). These results reveal that economic operators should be concerned about the control of quality/price ratio in order to maintain the competitiveness of their products/services.

Concerning the three variables that are not normally addressed in the augmented gravity models, the results show that an increase of $1 \%$ in the number of direct flights to Madeira causes an increase in demand of $0.227 \%$ in the short-run and $0.547 \%$ in the long-run. As expected, we find a positive and statistically significant relationship between the number of non-stop flights and international tourists' arrivals. International air connectivity between the departure and destination airport allows a reduction in travel time, and, hence, the opportunity cost of travel and convenience associated with travel. The results also suggest that promotion expenditures have played a statistically significant role in influencing tourist arrivals to Madeira. For each increase of $1 \%$ in promotion expenditures the international tourist arrivals increase $0.111 \%$ in the short-run and $0.267 \%$ in the long-run. This result is particularly important at a time when the pandemic COVID19 requires governments to increase social and health spending and to cut other expenditure items. For example, Sigala (2020) questions the role that destination management organizations should play in the post-pandemic of COVID-19. This result contributes to the debates that have already started about the governmental behaviour on the future of tourism and destinations tourism policy making and strategies (e.g., Sigala, 2020).

The climate variable suggests a positive statistically significant effect as a result of the distance in climatic conditions between home and destination countries. Elasticities show an increase of international arrivals of $0.175 \%$ and $0.421 \%$ for each $1 \%$ increase in climate distance in the short and long-run, respectively. This result shows the importance of climate as a competitive factor, as previously highlighted by Oliveira and Pereira (2008). Climate results should be read with caution, given that Madeira and source markets have microclimate. Given that climate averages are calculated based on their capitals, they tend not to correctly capture climate differences for all geographic points in both territories.

Finally, the dummy variable included in the model shows that the financial crisis and natural disasters (floods and mudslides) that occurred in 2010 in Madeira led to a fall in international tourist arrivals.

To test the stability of estimated coefficients across countries, we compare the coefficients estimated by using 2 subsamples of countries (the 3 most important origin markets and the remaining 10 countries), with the results of the estimation using the total sample (13 countries). The results in Table 2 indicate that the estimated coefficients for both subsamples are very similar to the ones for the total sample. 


\section{Conclusion and policy implication}

In this study, an augmented panel gravity model for tourism is used to identify the determinants of international tourist arrivals in an island destination. The results show that traditional gravity factors are statistically significant in explain demand in Madeira. In fact, origin income, prices, and cost of transportation are all key determinants. Other variables, such as promotional expenditures, direct flights, and climate, usually not included in the gravity models also show statistical significance.

A result that deserves to be highlighted is the high significance of habit persistence/'word-ofmouth' effect. Specific characteristics of tourism demand depend on factors that are not strictly economic, where we can include the habits and preferences of international tourist arrivals. In fact, 'word-of-mouth' can play a role in destination selection as important as commercial advertising. This means that decision-makers and economic operators should put in priority the comfort of tourists, offering tourism products/ services of high quality and upgrade their brands' image. This recommendation is in line with the conclusion that tourism in Madeira is a luxury good. This implies that promotion strategies must focus on high-income countries (e.g., the USA and Canada) and from fast-growing large economies (e.g., Russia, Brazil, China), where there are tourists who can afford luxury holidays.

The statistically significant effects of both price variables (relative cost of living and substitute price) reveal that price competitiveness is also a strong determinant that should be controlled by the regional government authorities. High attention must be paid to the control of the price/quality relationship and, given that prices in Madeira are no longer low, the strategy should be to increase the quality of services. More effective competitive strategies should focus on value for money, innovation, and product differentiation, instead of price reduction.

The accessibility to the islands is another extremely important factor in terms of tourism attractiveness. More direct flights should be established to countries that have a high potential demand for Madeira. Although the cost of travel and accessibility are important factors, the attractiveness of a destination is a key determinant for air travel demand. Regional promotion agency and regional authorities should itself try to increase the number of direct flights by improving all relevant pull effects on demand, through investment in infrastructure, targeted marketing, and the provision of new and innovative tourism products. Moreover, transportation costs should also be controlled to ensure sustainable tourist arrivals. As is known from previous studies, tourism to the Islands is sensitive to the cost of travel.

Despite the importance of word-of-mouth in attracting tourists to Madeira, the results reveal that promotion expenditures also play an important role in the selection of destination. The latter proves to be very important in promoting the different products offered by Madeira and in building the destination's high-quality image. Consequently, both promotion strategies can cohabit. With the emergence of the COVID-19 pandemic, governments and destinations have been providing stimulus packages and interventions (e.g., tax reliefs, subsidies, deferrals of payments) to ensure the viability and continuity of tourism firms and jobs. Consequently, the government has become a much bigger actor in the tourism economy. Debates have already started questioning the effectiveness of such interventions and their impacts in terms of austerity and cuts of public expenditure (e.g., Sigala, 2020). Given the results obtained by us for tourism promotion in Madeira, what are the correct tourism and destinations tourism policy making and strategies? Future research looking into these issues is highly warranted. It is true that tourism promotion contributes to achieving tourism revenues, future studies on the return of tourism promotion investments in the post-pandemic of COVID-19 are needed.

Finally, concerning the climate, the decisionmakers should consider targeting other countries whose 'climate distance' is largest to mitigate the harmful effects of any drop in demand from the main markets and invest additional promotion efforts in these markets. The region's policymakers should consider targeting other markets whose 'climate distance' is largest during periods when traditional markets are stagnant and invest additional marketing efforts in these markets.

However, these results must be taken with some caution. Firstly, due to lack of relevant airfare data, the use of oil price as a proxy for transportation costs becomes an inevitable limitation of this study. Second, due to a lack of climate data, we were unable to construct the climate index used by Lorde et al. (2016), which captures the question of climate in a more complete way. 
Third, ignores the amounts invested individually by economic operators. Fourth, future studies should investigate the importance of other explanatory variables (e.g., language barriers; cultural distance; socio-psychological dimension; among others).

\section{Declaration of conflicting interests}

The author(s) declared no potential conflicts of interest with respect to the research, authorship, and/or publication of this article.

\section{Funding}

The author(s) disclosed receipt of the following financial support for the research, authorship, and/or publication of this article: This paper is financed by Portuguese national funds through FCT - Fundação para a Ciência e a Tecnologia, I.P., projects numbers UIDB/00685/2020 (António Martins) and UIDB/04007/2020 (Susana Cró).

\section{ORCID iD}

António Miguel Martins (D) https://orcid.org/ 0000-0001-7082-5460

\section{Notes}

1. All statistical information on the island of Madeira was collected from the Regional Directorate of Statistics of Madeira, which is available here: https:// estatistica.madeira.gov.pt/en/.

2. For this good momentum in terms of tourism has contributed the many awards that the region has gained in tourism, such as the award for best island destination in Europe. For detailed information see: https://www.worldtravelawards.com/award-eur opes-leading-island-destination-2020.

3. Levadas cover almost all the Madeira Island and residents and tourists use them for taking walks. For more information about levadas, please see: https://walkmeguide.com/en/ and https://walkme guide.com/en/what-is-a-levada/.

4. Please, see the previous footnote.

5. All public goods exhibit two important characteristics: non-rivalry and non-excludability. Nonrivalry means that the consumption of the product by one person does not affect the ability of the others to consume the product. Non-excludability means that it is not possible to provide the product to one person without the benefits of the product being available to others. For more details see for example Atkinson and Stiglitz (2015).

6. For more details about the important objections to using the real exchange rate as a price proxy, please see Seetaram et al. (2016).
7. Only a Portuguese version of the document is available (competing destinations appear on page 14): http://www.visitmadeira.pt/Admin/Public/Down load.aspx? file $=$ Files $\% 2$ FFiles $\%$ FVisitMadeira $\%$ 2FEstudos\%2Fj-DOCUMENTO-ESTRATEGICO2017-21.pdf.

8. For more information about the storm of February 2010: https://www.nytimes.com/2010/02/22/ world/europe/22portugal.html and https://en.wiki pedia.org/wiki/2010_Madeira_floods_and_mud slides.

9. https://databank.worldbank.org/source/worlddevelopment-indicators.

10. http://www.cepii.fr/.

11. https://data.imf.org/.

12. https://www.apmadeira.pt/en/.

13. https://www.ipma.pt/en/oipma/onde/madeira/

14. https://www.ncdc.noaa.gov/cdo-web/search.

15. If long-run equilibrium is assumed, the following expression should be true: $\ln T A_{i, t}=\ln T A_{i, t-1}$. The corresponding long-run elasticities have then been calculated by dividing each of the estimated coefficients by $\left(1-\beta_{1}\right)$.

\section{References}

Algieri B (2006) An econometric estimation of the demand for tourism: the case of Russia. Tourism Economics 12(1): 5-20.

Arellano M and Bond S (1991) Some tests of specification for panel data: Monte Carlo evidence and an application to employment equations. The Review of Economic Studies 58(2): 277-297.

Aslan A, Kaplan M and Kula F (2008) International tourism demand for Turkey: a dynamic panel data approach. MRPA Paper n. ${ }^{\circ}$ 10601. Available at: https://mpra.ub.uni-muenchen.de/10601/1/ MPRA_paper_10601.pdf (accessed 25 November 2020).

Atkinson AB and Stiglitz JE (2015) Lectures on Public Economics: Updated Edition. Princeton, NJ: Princeton University Press.

Chasapopoulos P, Den Butter FA and Mihaylov E (2014) Demand for tourism in Greece: a panel data analysis using the gravity model. International Journal of Tourism Policy 5(3): 173-191.

Cró S and Martins AM (2017) Structural breaks in international tourism demand: Are they caused by crises or disasters? Tourism Management 63: 3-9.

Crouch GI (2011) Destination competitiveness: an analysis of determinant attributes. Journal of Travel Research 50(1): 27-45.

Crouch GI, Schultz L and Valerio P (1992) Marketing international tourism to Australia: a regression analysis. Tourism Management 13(2): 196-208. 
Deluna R Jr, and Jeon N (2014) Determinants of international tourism demand for the Philippines: an augmented gravity model approach. MRPA Paper n. ${ }^{\circ}$ 55294. Available at: https://mpra.ub.uni-muen chen.de/55294/1/MPRA_paper_55294.pdf (accessed 11 November 2020).

Dropsy V, Montet C and Poirine B (2020) Tourism, insularity, and remoteness: a gravity-based approach. Tourism Economics 26(5): 792-808.

Faulkner B (1997) A model for the evaluation of national tourism destination marketing programs. Journal of Travel Research 35(3): 23-32.

Fayos-Solá E (1996) Tourism policy: A midsummer night's dream? Tourism Management 17(6): 405-412.

Fourie J and Santana-Gallego M (2013) The determinants of African tourism. Development Southern Africa 30(3): 347-366.

Fujii E, Im E and Mak J (1992) The economics of direct flights. Journal of Transport Economics and Policy 26(2): 185-195.

Garín-Muñoz T and Montero-Martín LF (2007) Tourism in the Balearic Islands: a dynamic model for international demand using panel data. Tourism Management 28(5): 1224-1235.

Grosche T, Rothlauf F and Heinzl A (2007) Gravity models for airline passenger volume estimation. Journal of Air Transport Management 13(4): 175-183.

Habibi F (2017) The determinants of inbound tourism to Malaysia: a panel data analysis. Current Issues in Tourism 20(9): 909-930.

Hay B (2019a) Are national tourism organisations past their sell-by date? A perspective article. Tourism Review 75: 170-173.

Hay B (2019b) The future of national tourism organisations marketing functions - There is no future? Journal of Tourism Futures.

Hsiao C (2014) Analysis of Panel Data. Cambridge: Cambridge University Press.

Jeffries DJ (2001) Governments and Tourism. London: Routledge.

Khadaroo J and Seetanah B (2008) The role of transport infrastructure in international tourism development: a gravity model approach. Tourism Management 29(5): 831-840.

Kulendran N and Dwyer L (2009) Measuring the return from Australian tourism marketing expenditure. Journal of Travel Research 47(3): 275-284.

Kumar N, Kumar RR, Patel A, et al. (2020) Modelling inbound international tourism demand in small Pacific Island countries. Applied Economics 52(10): 1031-1047.

Ledesma-Rodríguez FJ, Navarro-Ibáñez M and PérezRodríguez JV (2001) Panel data and tourism: a case study of Tenerife. Tourism Economics 7(1): 75-88.
Lorde T, Li G and Airey D (2016) Modeling Caribbean tourism demand: an augmented gravity approach. Journal of Travel Research 55(7): 946-956.

Lundtorp S (2003) Free Riders in Tourism. Denmark: Centre for Regional and Tourism Research. Working Paper . $^{\circ}$ 18. Available at: https://crt.dk/wpcontent/uploads/10_workingpaper_FreeRiders_in_ tourism.pdf (accessed 8 November 2020).

Morley C, Rosselló J and Santana-Gallego M (2014). Gravity models for tourism demand: Theory and use. Annals of Tourism Research 48: 1-10.

Nicolau JL and Màs FJ (2006) The influence of distance and prices on the choice of tourist destinations: the moderating role of motivations. Tourism Management 27(5): 982-996.

Oliveira P and Pereira PT (2008) Who values what in a tourism destination? The case of Madeira Island. Tourism Economics 14(1): 155-168.

Park JY and Jang S (2014) An extended gravity model: applying destination competitiveness. Journal of Travel \& Tourism Marketing 31(7): 799-816.

Park SY and Pan B (2018) Identifying the next nonstop flying market with a big data approach. Tourism Management 66: 411-421.

Petit S and Seetaram N (2019) Measuring the effect of revealed cultural preferences on tourism exports. Journal of Travel Research 58(8): 1262-1273.

Pike S and Page SJ (2014) Destination marketing organizations and destination marketing: a narrative analysis of the literature. Tourism Management 41: 202-227.

Seetanah B, Durbarry R and Ragodoo JN (2010) Using the panel cointegration approach to analyse the determinants of tourism demand in South Africa. Tourism Economics 16(3): 715-729.

Seetaram N (2010) Computing airfare elasticities or opening Pandora's box. Research in Transportation Economics 26(1): 27-36.

Seetaram N, Forsyth P and Dwyer L (2016) Measuring price elasticities of demand for outbound tourism using competitiveness indices. Annals of Tourism Research 56: 65-79.

Sigala M (2020) Tourism and COVID-19: impacts and implications for advancing and resetting industry and research. Journal of Business Research 117: 312-321.

Song H, Qiu RT and Park J (2019) A review of research on tourism demand forecasting: launching the annals of tourism research curated collection on tourism demand forecasting. Annals of Tourism Research 75: 338-362.

Tatoglu FY and Gul H (2020) Analysis of tourism demand using a multi-dimensional panel gravity model. Tourism Review 75(2): 433-447. DOI: 10.1108/TR-05-2019-0147. 
Tveteras S and Roll KH (2014) Non-stop flights and tourist arrivals. Tourism Economics 20(1): 5-20.

Uysal M and Crompton JL (1984) Determinants of demand for international tourist flows to Turkey. Tourism Management 5(4): 288-297.

Uysal M and O'Leary JT (1986) A canonical analysis of international tourism demand. Annals of Tourism Research 13(4): 651-655.

Winters LA and Martins PM (2004) When comparative advantage is not enough: business costs in small remote economies. World Trade Review 3 (3): 347-383.
Witt SF and Witt CA (1995) Forecasting tourism demand: a review of empirical research. International Journal of Forecasting 11(3): 447-475.

$\mathrm{Xu} \mathrm{L}$, Wang S, Li J, et al. (2019) Modelling international tourism flows to China: a panel data analysis with the gravity model. Tourism Economics 25(7): 1047-1069.

Yazdi SK and Khanalizadeh B (2017) Tourism demand: a panel data approach. Current Issues in Tourism 20(8): 787-800.

Zhang HQ, Kulendran N and Song H (2010) Measuring returns on Hong Kong's tourism marketing expenditure. Tourism Economics 16(4): 853-865. 